\title{
Management of the Real Estate Market in Vietnam with Lessons from Poland
}

\author{
Vu Ngoc Xuan ${ }^{1}$ \\ ${ }^{1}$ Director Centre, Faculty of Economics, National Economics University \\ Address (207 Giai Phong Road, Hai Ba Trung Dist, Ha noi, Vietnam)
}

Email: xuanvn [AT] neu.edu.vn

\begin{abstract}
Vietnamese economy in the year 2017 reached a GDP growth rate of 6.81\%, inflation was controlled at 3.53\%. According to Prime Minister Nguyen Xuan Phuc, Vietnam's economy has overcome many difficulties with the recovery and higher growth. In 2017, the size of the GDP economy will be about \$220 billion, GDP by purchasing power parity - PPP \$600 billion, per capita GDP of \$2,385, and GDP per capita PPP is 6,000 US dollars. As predicted by the General Statistics Office, Vietnam's GDP in the next two years is expected to increase by 6.8\%, and 7\%. The exchange rate between the Vietnamese dong and foreign currencies such as the US dollar, the yen and the euro remains stable, while a trade surplus of \$ 2.67 billion in 2017, slightly up from \$2.52 billion US surplus in 2016. In addition to the macroeconomic highlights, Vietnam's economy faces challenges due to bad debt from the decline of the real estate market in the past, the bad debt ratio The banking system is high with interest rates falling but still at high levels, many businesses still find it difficult to mobilize business capital. At present, the drastic direction in the direction and management of the State Bank, the birth of the company VAMC recently brought the bad debt ratio of banks to an average of less than 5\%. In this article, the author discusses the lessons learned from the management of the real estate market in Poland to provide a number of measures to increase liquidity in the real estate market in Vietnam economic growth in the future.
\end{abstract}

Keywords - Vietnam Property Management Company (VAMC), mortgage liabilities (CDO), Polish Real Estate Association (REAS), International Monetary Fund (IMF), gross domestic product GDP), purchasing power parity (PPP).

\section{INTRODUCTION}

The real estate market is one of the most important markets in the market economy as it directly relates to a huge amount of wealth in terms of scale, nature and value of commodities in economy. Real estate is a great asset of every nation. The proportion of property in the total wealth of society is different of the countries but usually accounts for about $40 \%$ of each country's material wealth. Real estate activities accounted for $30 \%$ of total economic activity. According to experts, the total value of untapped capital in real estate in third world countries is huge, about trillions of dollars, more than the total ODA of developed countries available to developing countries in the past 30 years. Real estate is also a big asset for every household. In the economy, the main functions of the real estate market are the place of residence, the place where the family operates ... The real estate also generates capital for development through mortgage activity. Industries related to real estate also have a major impact on banking operations. We can look back at what happened during the global financial crisis in the second half of 2007 and the first months of 2008 to see this.

Actual data suggest that average house prices in Poland from 2007 to 2016 may be driven by both Polish government policy and culture. The Polish population is almost unchanged from 38.639 million in 1997 and 38.638 million in 2017. Households also determine the characteristics of long-term housing needs, including the area of housing and the number of rooms in the house of household. There is a tendency to see a decrease in the number of people per household in Poland. By 2017, Poland has a GDP of \$ 470 billion and GDP per capita of \$ 12,539. GDP growth rate in recent years in Poland is 3\% per year. In Poland, housing prices on high incomes, rising rents in big cities, and the large number of sparse commercial centers are lessons for Vietnam in developing and managing the real estate market in the future. 


\section{MANAGING REAL ESTATE MARKET IN BRAZIL}

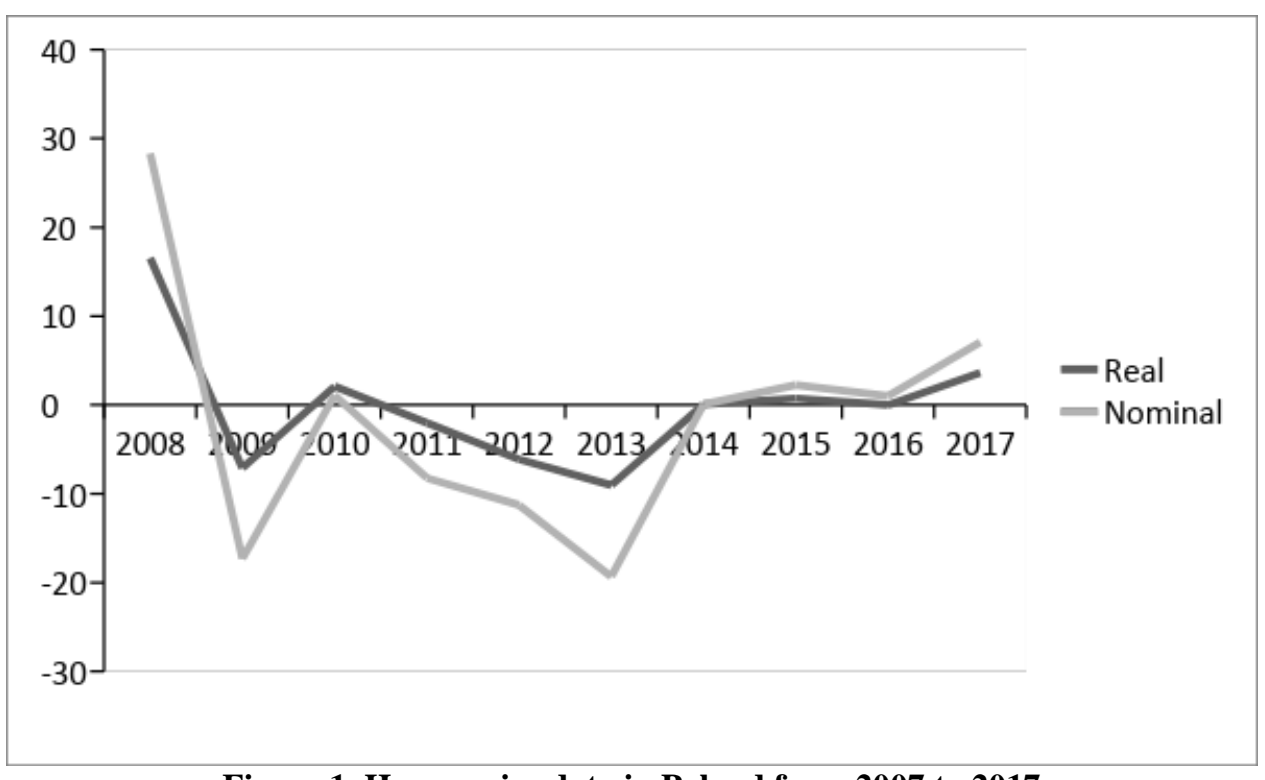

Figure 1. House price data in Poland from 2007 to 2017

(Source: Polish Central Bank visit http://www.globalpropertyguide.com)

With record low interest rates, limited home supply, new housing subsidies, and housing demand in Poland continue to rise sharply. Surprisingly, the rise in house prices has slowed down in seven major Polish cities (Warsaw, Gdańsk, Gdynia, Kraków, Łódź, Poznan, and Wrocław). Specifically, house prices rose slightly by $0.3 \%$ (after adjusting inflation by $1.3 \%$ ) throughout 2017. In the latest quarter, house prices in Poland rose $0.1 \%$ (0.8\% adjusted for inflation). Figure 1 shows that real estate prices in Poland in the past 10 years from 2008 to 2018 were almost negligible. In the period from 2008 to 2014, home prices tend to decrease almost all over the country. From 2014 up to now, housing prices in Poland tend to increase slightly. This reflects a stable real estate market and not much fluctuation in Poland.

Warsaw has the most expensive housing in the country, with an average selling price of PLN 8,658 (EUR1,975) per square meter. The next is Kraków, a city with many UNESCO World Heritage sites, with an average price of PLN6,827 (EUR1,558) per square meter, Gdynia for PLN6,407 (EUR1,462) per meter square .. and Gdańsk with PLN6,193 (EUR1,413) per square meter. Zielona Góra has the cheapest housing in Poland, with an average price of only EUR786 per square meter. In 2017, the Polish economy increased up 3\% over the same period last year. Economic growth is expected to remain robust in the coming years, according to IMF forecasts. Poland will grow by $3.6 \%$ and $3.7 \%$ in 2018 and 2019.

\section{Polish sales will increase slightly In}

Total about 14,300 houses sold in Poland in the first quarter of 2017, up 24.8\% over the same period last year, according to data from the Polish real estate association. In six major Polish markets, home sales reached nearly 54,700 units from Q2 2017 to Q1 2017, up 25.8\% from the same period last year, according to data from the Polish real estate association REAS. . The number of flats launched in Q1 2017 increased 21.7\% over the same period and reached 13,700 houses. As a result, the number of units occupied by the end of Q1 2017 increased 1.3\% to 48,300 homes compared to last year. Buyers use government subsidies. The Polish government provides a subsidy program for young people who want to buy a home, with interest-free loans to encourage young people to own a home instead of the apartments for rent. In Poland, people are very interested in investing real-estate; most of the people invest in housing for the purpose of buying for rent. This is partly due to the low interest rates on bank deposits from 1990 up to now, low inflation, as well as stable rental rates, the attractiveness of rental investment remains high for the population.

Housing prices in major Polish cities are still lower than the peak before the crisis in mid-2008. But the number of people failing due to the collapse of the real estate market is negligible, because the government has Measures to dramatically narrow the boom of the Polish housing market from 2004 to 2007. When Poland joins the EU, the real estate market is driven by the wave of investment from EU countries. The real estate market boomed by record low interest rates and housing mortgage market developments. Low interest rates made the real estate market surge dramatically in Warsaw - up 23\% in 2005, up 28\% in 2006, $45 \%$ in 2007, and $13 \%$ in 2008. Other cities like Wroclaw's home prices even escalate at a rapid pace.

Behind the boom in Poland's new years of EU accession is a wave of speculation and new capital from EU countries. However, the 2008- 2009 economic crisis has significantly reduced the value of the Polish Zloty, and as a 
result, home mortgages - mainly of foreign currency - have become bad loans and are no longer available payment system. As a result, house prices fell for six consecutive years. Housing prices in seven major Polish cities fell by $13.8 \%$ (-25.3\% adjusted for inflation) from 2008 to 2013.

\section{Mortgage lending rates continued to fall for several years at three spread}

The average interest rate mortgages in Poland fell slightly to average 3.5\% / year in 2017, from 3.6\% / year in the same period last year, according to figures from the central bank Polish National Bank - NBP. Polish central bank maintains its key interest rate unchanged for 16 consecutive months to the present time, at a historic low of $1.5 \%$. Although the inflation index is falling, the current base rate in Poland is expected to remain unchanged in the near future. Maintaining low interest rates is beneficial for keeping the Polish economy on the path to sustainable development. Ongoing, the new central bank governor, "Brexit is not an earthquake, and so far it has not affected Poland," said Adam Glapinski. The UK withdrawal from the EU caused great uncertainty, but the best option in this situation is to wait and see England have a real influence on the EU unity.

The number of rental properties has increased sharply, along with the demand for housing in Poland. The total number of rental properties in Warsaw increased, ranging from 5.5\% to 6.5\%. In Krakow, the number of rental properties increased from $4.74 \%$ to $6.77 \%$. In the capital, Warsaw, in the Mokotow district, is located just below Srodmiescie, where there are embassies and many companies of foreign companies. An apartment with an average area of 120 square meters, profitability of investment apartments in Mokotow about $6.45 \%$ per year. The apartments in the Srodmiescie area, near the historic Old Town (Old Town) and New Town (Nowe Miasto), offer a range of serviced apartments ranging from $5.5 \%$ to $5.8 \%$ per annum. At other popular Warsaw areas Ursynów, Wilanów, and Żoliborz, flats offer a good return of around $6.4 \%$ per annum. In Krakow, flats have a profitability ratio ranging from $4.7 \%$ to $6.7 \%$ per year. Thus, the ancient city of Krakow has the most attractive market in Poland. However, the major disadvantage is that high housing prices increase travel costs in Krakow and the capital Warsaw.

Renting an apartment is an inevitable choice for more and more Poles, because of the stricter requirements for home mortgages, the uncertainty of the labor market and the unemployment rate. above $6 \%$. On the other hand, the labor market in Poland has low growth prospects, not encouraging households to bear long-term debt. The influx of people from other cities to the capital, especially students or young people looking for work, has also led to increased demand for rental housing in major cities. According to figures from the General Statistics Office of Poland, 21\% of households rent apartments in the capital Warsaw, with half of them renting social and community housing. Most of the residential property in Poland is privately owned. While only $10.7 \%$ of total housing is rented at lower prices, with $5.7 \%$ of communal or communal dwellings. $2.1 \%$ of rent cooperatives, $1.2 \%$ rent of state-owned companies, $1.2 \%$ of houses in the State Treasury.

\section{Construction activity in residential areas in Poland increased in the near future}

In Q1 2017, the number of building permits increased by $9.9 \%$ over the same period to reach 42,200 units, according to data from the total Polish Statistical Office- CSO. At the same time, the number of home builders also increased $7.9 \%$ to 34,300 units while the number of completed homes increased $2.5 \%$ to reach 717,500 units.

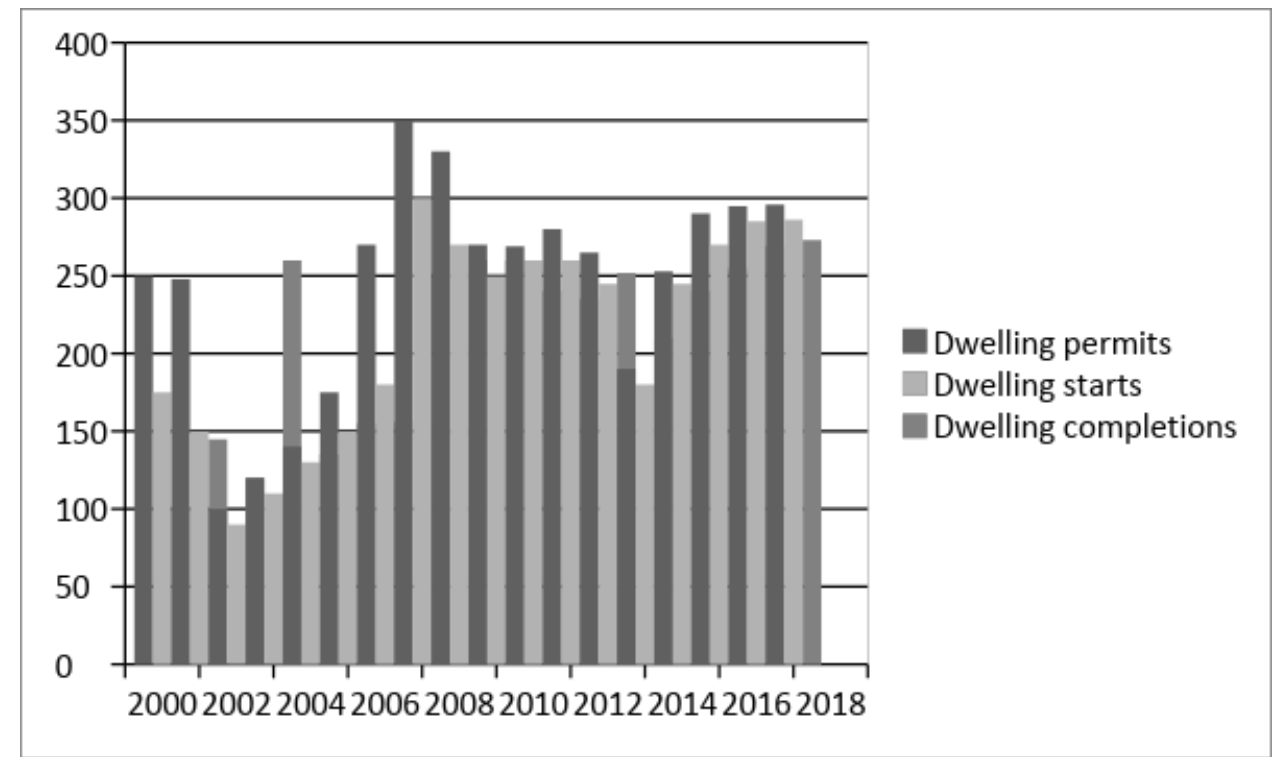

Figure 2. Housing construction data in Poland from 2000 to 2017 (Source: Polish Central Statistical Office) 
Figure 2 shows the number of licensed houses, number of completed houses and number of completed houses construction in Poland from 2000 to 2017, data show that the number of licensed houses, start-up and completion of construction in recent years in Poland grew slightly and reached an approx. 250 thousand to 300 thousand houses every year. Thus, the data show that the activity of asking for permission to build, start construction and completion of housing of Poles in recent years has grown slightly in recent years.

In the first quarter of 2017, the number of completed homes rose $18 \%$ to 37,400 units compared to the same period last year. A significant proportion of Polish residents are built by private investors, rather than by state-owned housing companies. The Polish housing market is behind the quality of Western Europe, housing life, and aging population and negative population growth, so the real estate market in Poland is already at a high level market. Of the $13,850,000$ inhabitants in Poland, about $72 \%$ of the houses were built before 1989, mainly in the communist era using prefabricated and prefabricated building technology; the house is of very poor quality. Modern houses built from 2000 onwards occupy about $12 \%$ of the total and are concentrated in six major cities: Warsaw, Krakow, Poznan, Wroclaw, Tricity, and a few houses in Lodz has strictly managed the planning of building houses and land used to build houses planned according to the plan, accounting for less than $30 \%$ of the country. The revision of the master plan requires administrative procedures ranging from a few months to a year.

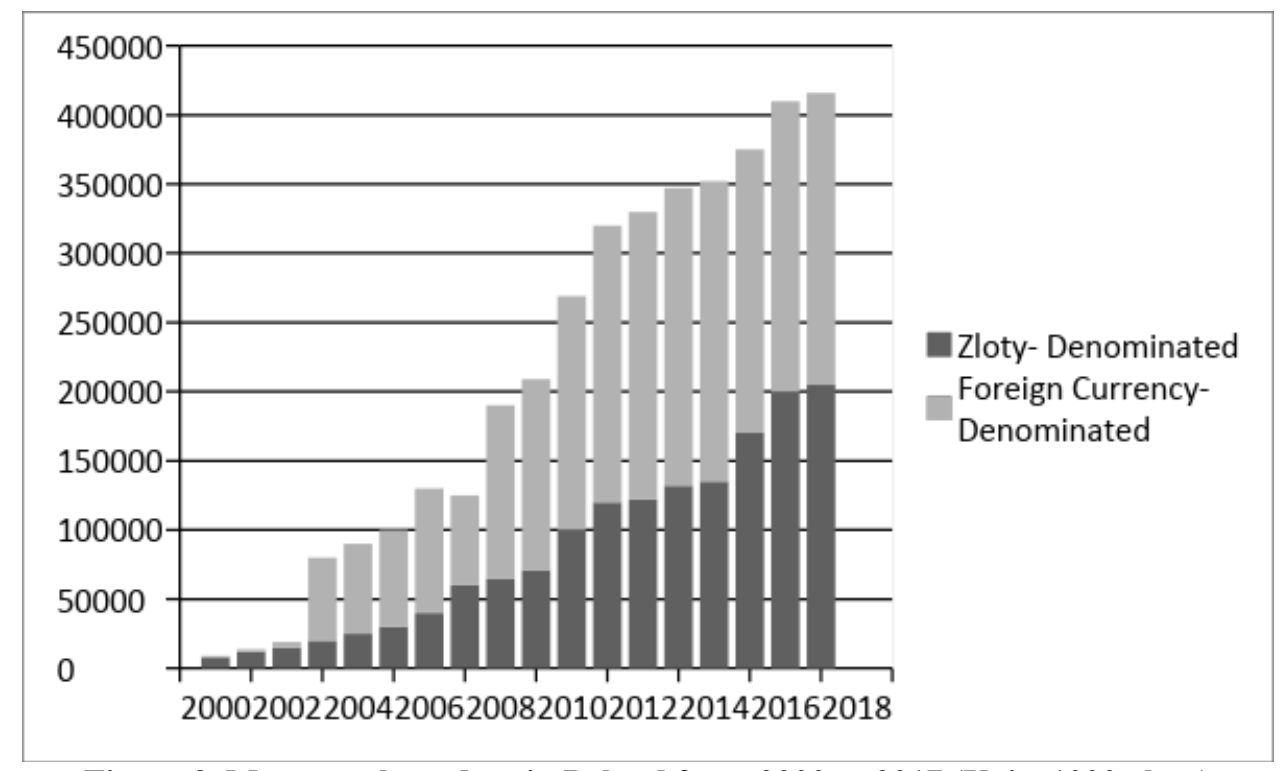

Figure 3. Mortgage loan data in Poland from 2000 to 2017 (Unit: 1000 zloty)

(Source: General Statistics Office of Poland)Poland

Figure 3 shows the data on mortgage loans in Poland's mortgage-backed mortgages over the past ten years with only $1.3 \%$ of GDP in 2000 (about 50 billion zloty) have risen to 9, 9\% of GDP (about 100 billion dollars) in 2007, and 21\% of GDP (about 400 billion dollars) by 2017 - but still lower than international standards. The expansion of the mortgage lending market can be attributed to rapid growth in both domestic and foreign zloty-denominated housing loans in recent years.

In April of this year, total mortgage lending increased by $2.2 \%$ over the same period last year to reach PLN379.73 billion (EUR 86.64 billion), according to the Central Bank of Poland (NBP). Apart from Polish citizens increasing mortgage loans to buy houses, foreign investors are also factors boosting demand. Home loans in Poland were only about $2 \%$ in 1996 , with the proportion of home loans in foreign currency (including Swiss franc loans) reaching a peak of more than $69 \%$ in 2008 . However, the rate has fallen to about $44 \%$ in 2017 . The reason for the crisis in 2008 , the zloty currency devalued significantly against the euro, many Poles bankrupt when borrowing mortgage in foreign currency. Thus, people are more cautious about joining a mortgage in foreign currency.

Figure 4 shows the GDP of Poland from 1990 to present. In 1990, when the Polish economy was transformed into a market economy and the Communist Party was no longer in power in Poland, its GDP was only \$100 billion in 1990. Poland's economy has grown steadily for more than 20 years past. However, Poland's GDP peaked at $\$ 500$ billion in 2008. In recent years, Poland's economic outlook has been very positive. The economic growth rate in Poland is always around 3\% per annum, but the GDP in 2018 is only about 470 billion dollars and has not yet recovered to its peak in 2008 . 


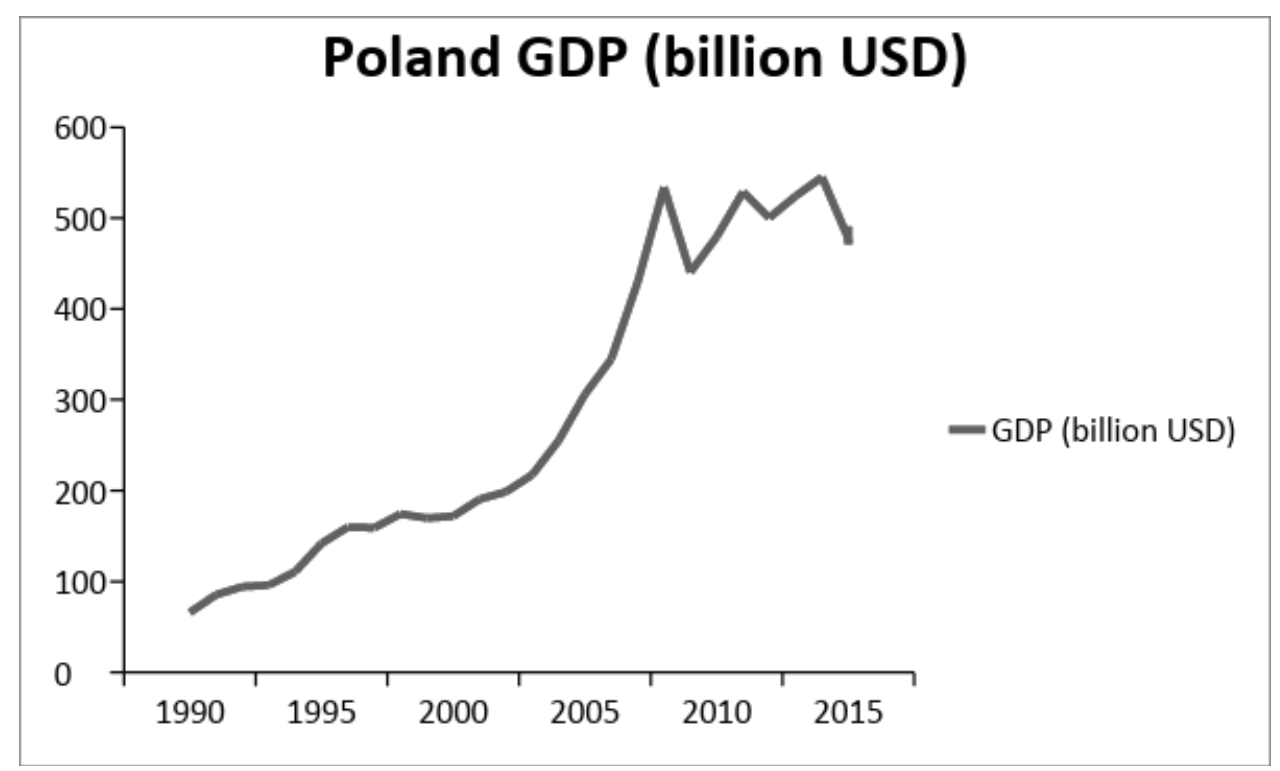

Figure 4. Poland GDP from 1990 to 2017

(Source: World Bank report 2017)

In 2015 , the Polish economy increased by a robust $3.8 \%$, the fastest pace since 2012 , mainly due to domestic demand. Economic growth is expected to remain strong at 3.6\% this year 2018 and 3.7\% in 2017, according to the IMF. In Poland, the zloty is used and not used in Euros. Poland is the only country in Europe to avoid a recession in the global financial and economic crisis.

In the past, the Polish economy grew by $3.9 \%$ in $2008,2.6 \%$ in $2009,3.7 \%$ in 2010 and $5 \%$ in 2011 , according to the IMF. However, economic growth slows in 2012 and 2013, with GDP growth of only $1.6 \%$ and $1.3 \%$, respectively, caused by the economic downturn in the Euro zone, where more than $50 \%$ of exports of the Polish economy. Poland rebounded in 2014 with growth of 3.3\%, driven by domestic demand growth. In May 2015, the party (PiS) with candidate Andrzej Duda won the presidential election, replacing President Bronislaw Komorowski. Duda, a conservative, won $51.55 \%$ of votes, while Komorowski only won $48.45 \%$. The new president, who assumed office in August 2015, pledged to reduce the retirement age, and raise taxes to increase subsidies for the poor. In 2016 and 2017, Poland's economy grew by $2.9 \%$ and $3 \%$ over the same period last year, down from $3.8 \%$ in 2015 .

Recently, Fitch Ratings Poland A- and A's credit rating, due to budget deficit in Poland, fell to an 8-year low of only $2.6 \%$ of GDP in 2015, compared to $3.3 \%$ in $2014,4 \%$ in 2013 , , 4.9\% in 2012, and $7.5 \%$ in 2011 , according to the European Commission. However, the deficit is expected to rise to 2.8 percent of GDP this year and 2018 to more than 3 percent of GDP in 2019 to fulfill the President's promise before the election. Public debt of the Polish government is about 51.3\% of GDP by 2015, down from 56\% in 2013. Public debt is projected to rise to 53.2\% of GDP by 2018 .

Figure 5 shows data on Unemployment rate in Poland since 1990. The unemployment rate in Poland has always remained high during the past few years, with the unemployment rate reaching $20 \%$ in 2004 . Recently, the unemployment rate has dropped to $9.1 \%$ by 2016, down from $10.7 \%$ in 2015 . The unemployment rate in 2017 has fallen to about $8 \%$ but remains high compared to many other countries. Employment issues are the primary concern of young people in Poland. 


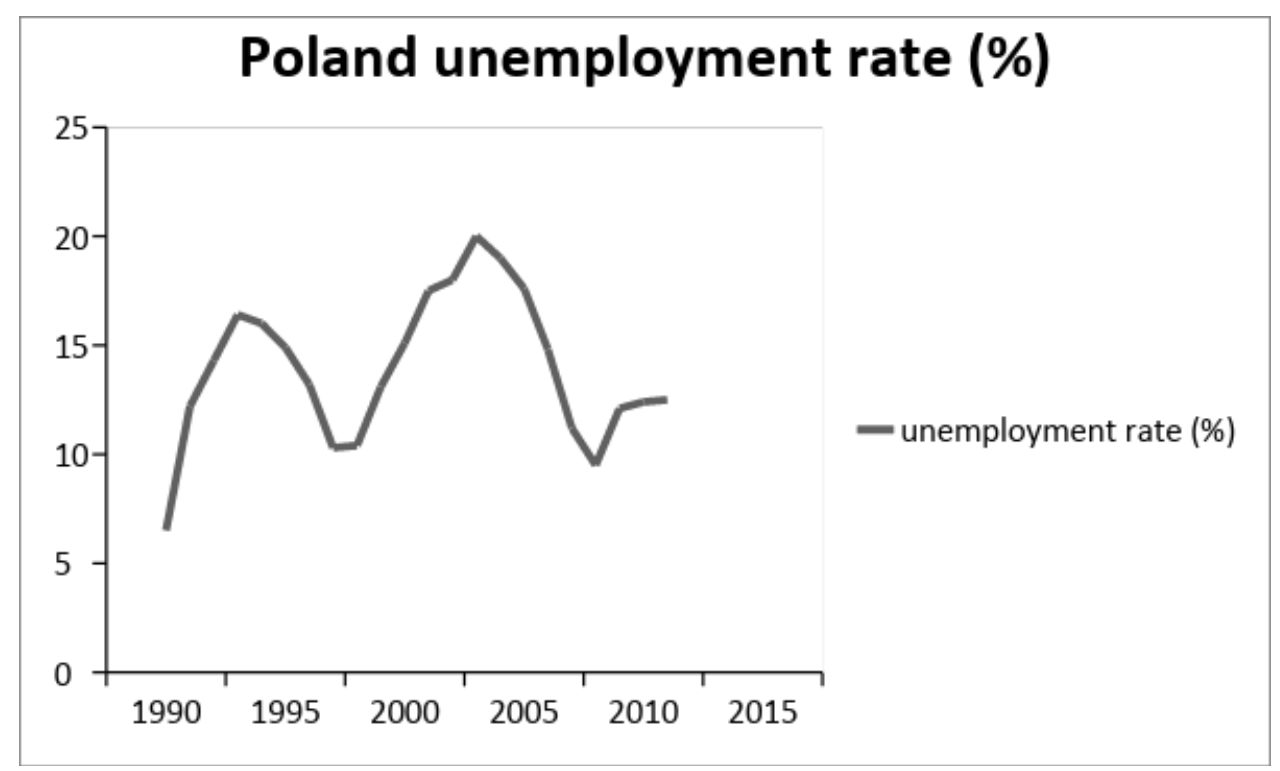

Figure 5. Unemployment rate in Poland from 1990 to 2017

(Source: General Statistics Office of Poland)

\section{SOME RESTRICTIONS ON VIETNAM REAL ESTATE MARKET}

Figure 6 shows the area of housing built in Vietnam from 2005 to date. Data show that the area of housing construction in Vietnam in 2005 was about 40 million square meters, of which nearly $100 \%$ were private houses. However, the area of apartment construction has increased sharply recently. In 2017, the area of private construction is about 80 million $\mathrm{m} 2$, apartment area of about 40 million $\mathrm{m} 2$. Thus, to meet the demand for housing of the people, in more than ten years the area of housing construction of Vietnam has tripled.

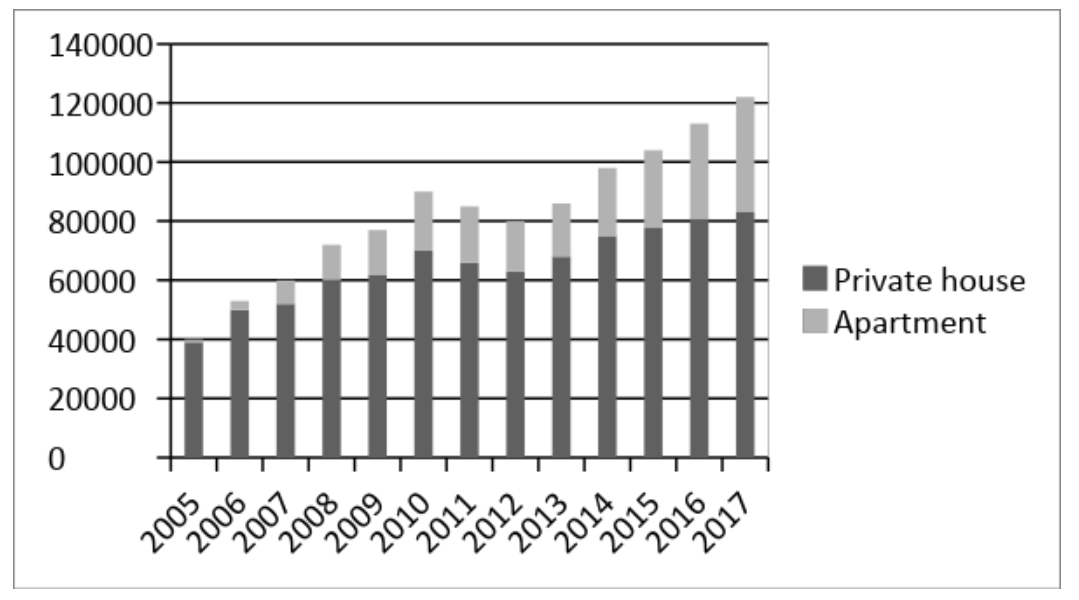

Figure 6. Construction area in Vietnam from 2005 to 2017 . Unit: $1000 \mathbf{~ m}^{2}$

(Source: General Statistics Office of Vietnam)

A good economy must be based on a thriving real estate market, if the real estate market is crumbling and falling, the economy will have to pay dearly. Real estate is an important factor for any economy; however, if all of the country's resources pour into this sector, the real estate market crisis will make the economy sharply weakened. It is important to clarify for businesses and investors the idea that real estate is an easy way to become rich. Short-term gains are really only for the minority and will only have damaging consequences on the economy over the long term. In addition, human resources of the country can be invested in the construction industry, technology, technology, but researchers point out that the resources in Vietnam poured into the land too much.

Real estate prices in Vietnam, currently at the highest level in the world (office rent in Ho Chi Minh City 17th highest in the world). The high demand for office space has made office rents in Hanoi and Ho Chi Minh City soar. Current Grade A office rents in 2017 in Ho Chi Minh City increased by 52\%, while rents in Hanoi increased by 30\%. For Grade B office rents in Ho Chi Minh City, prices have raised by $35 \%$, while in Hanoi, prices have increased by about 40\%. Grade C office rental in Ho Chi Minh City increased 35\% and in Hanoi increased by $45 \%$. The increase in office 
rents has increased the cost of doing business and will reduce the cost competitiveness of Vietnam's economy compared to other countries in the region.

The awareness of the nature, role and position of the real estate market among the population in Vietnam has made progress but still limited the system of real estate management from central to local. Ensure consistency and synchronization. Some factors have a great impact on the formation and development of real estate market management issues such as urban land, urban construction planning, investment, Different management, so lack of management of a unified agency leading to the overlap and overlap in the management of the real estate market in Vietnam.

The legal framework for the real estate market, although step by step improved, supplemented and amended, still has many shortcomings that need to be further amended. There are important policy mechanisms, such as policies to mobilize long-term capital for real estate market development such as transaction tax, real estate tax ... should soon study issued Conditions for the real estate market to develop stably, overcome the participation in buying, selling, and transfer ... in contravention of the law, causing loss of revenue for the budget. The recent proposal to levy tax on more than 700 million dollars in Treasury bills has caused controversy among the public. The proposal is to tax 0.3 to 0.4 percent on the value of the house over VND700 million to supplement the annual budget of VND30-60 trillion. Speculation, buying and selling real estate tax evasion is still common in many places, especially in large urban areas leading to the operation of the real estate market is unsustainable and unstable. In summary, there are some limitations in the real estate market in Vietnam compared to the real estate market in Poland:

Firstly, the competitiveness and transparency of the real estate market in Vietnam It is still low, especially in the primary market (land allocation, land lease). The mechanism of land auctions, project bidding for the selection of investors although defined in some laws, but the practical application is still limited, even many issues not yet implemented (allocation through tender for selection of investment projects regulated in the Land Law in 2003 but so far almost no project selected investor in this way). To achieve the goal of transparency for real estate transactions, real estate business, the law has defined the real estate business organizations to sell real estate through the trading floor, but the regulation This has not been done yet ... a lot of projects have been implemented, a lot of land has been converted from agricultural land to industrial and residential land. However, tracking the origin of housing projects put into circulation is very difficult in tracking and control. This difficulty (coming from both sides of the business and secondary investors) has created a very unclear market, increased speculation.

Secondly, real estate prices are too high compared to people's income as well as the development of the economy and the value of real estate, thus directly affecting the process of socio-economic development. Assembly and make the creation of a large area of housing segment low-income people face many difficulties.

Third, high land prices cause many consequences. Money will be transferred to small speculators. Farmers only receive a small portion of the land price increase. Investors and businesses must increase the cost of compensation, land clearance and access to land. When homes reach the end consumer, they pay the price too high sometimes silly. The poor, the majority of the low-income poor in Vietnam, will not be able to afford a high-priced home.

Fourth, the ability of debtors to repay and real estate speculation has reached an extremely dangerous limit. It is extremely important that the amount of money a middle-class family pays each month for a home loan in Vietnam is too high. International practice is that about one-third of the household's monthly income, i.e. a mere $30 \%$ of monthly income paid for dental care each month; each family should spend up to $33 \%$ to pay their mortgage. In Vietnam, the savings to buy a home is more than $80 \%$ of household income is an abnormal figure compared to countries like Poland.

\section{LESSONS LEARNED FOR VIETNAM}

The sharp decline in real estate in Vietnam began in early 2011, when the consumer price index (CPI) increased by nearly $20 \%$, the normal interest rate remained more than $20 \%$. Housing prices began to fall. From 4/2011 up to now, a strange phenomenon is appearing more and more articles in the newspaper warned about the high price of real estate (real estate) in Vietnam. The frequency of this information can only be compared with the "dark" phase of the real estate market in 2008 and early 2009. However, in the big waves land price increases in Hanoi took place from mid-2009 to early 2011, with prices pushed up nearly three times, quite surprised that the warning information on the real estate market is quite meager.

The question of the sharp decline of real estate is not a new topic as it has occurred in most countries around the world in 2006 and 2007. Lessons from Poland can help Vietnam very much. The land fever is often repeated and cyclical, this issue should be carefully considered, and often when the land fever is passing we can see that much is mentioned on the medium Mass media, that is, at the time when speculators almost finished selling. It is clear that the decline in house prices in the three years 2011-2013 led to the disappearance of large volume of real estate businesses. This resulted in the increase in bad debts in the bank, the construction company inundated with debt, many companies fired workers and employees were not paid.

In the four major waves of the real estate market nearly twenty years ago (waves belonging to the real estate market in Hanoi and Da Nang have spread to the south), perhaps the real estate bubble only mentioned So much after the wave of 
development from 2000 to 2001 for nearly five years, 2002-2006, we did not see a sharp drop in housing prices. Meanwhile, apartment segment has not been formed much. The investment in real estate is mainly land and houses, villas ... In recent years, the real estate market apartments and resorts boomed and developed strongly with large apartment output. Real estate investors such as Vinhomes, FLC ... continuously supply a large amount of apartments. Ground prices are currently hot in the market from north to south, only apartment prices are no longer hot fever phenomenon.

From analyzing the real estate market in Poland, it can be seen that in the era of globalization, Vietnam is a small country and the economic impact is inevitably affected by the great economies. Real estate bubbles boom in countries in the region and Vietnam is no exception. If real estate prices fall for three consecutive years, it will have a significant impact on economic growth and macroeconomic stability. The Government of Vietnam has implemented a number of measures to promote the development of the real estate market. We can see the bad debt ratio in Vietnam in recent years in the banking sector is mainly from the real estate market, so the government has taken some decisive measures to limit the impact of the decline in the real estate market and the strengthening of the real estate market will contribute to GDP growth in the coming years.

In fact, the implementation of the 30,000 billion packages to support low-income homebuyers has many shortcomings. This amount cannot be disbursed in the first stage due to administrative problems. However, the package of 30,000 billion disbursed in recent years also contributed to help low-income home buyers with interest rates of about $4.8 \%$ per year. Many people who buy low-income housing in Hanoi have to buy houses at a higher price than commercial houses. The complex administrative procedures, together with the low income housing construction, were assigned by the Hanoi People's Committee to some state-owned companies with high production costs and corruption, which made house prices lower than house prices. For example, some city officials in Hanoi reflect their low-income apartment buildings, far from the center, without elevators. price is 11 million VND / $\mathrm{m} 2$, the interest rate within 10 years is in the range of $16-24 \%$. While the current market price for low income people is only VND10-12 million / m2, mortgage rates at commercial banks are around 10-12\% per annum for a long period of 10-20 year. In order to improve and develop the real estate market in Vietnam, with the real estate management experience from Poland, the government should have some solutions as follows:

Firstly, compensation mechanism, face clearance Equalization and resettlement are still a problem with the shortcomings that need to be improved to overcome people's grievances. Construction and management of economic development planning - as well as land use planning, planning and urban planning must also be unified, transparent and transparent. People in rural areas can also access planning easily, simplifying land procedures are necessary to waste time and costs of the State and investors. Allowing authority within the scope of converting agricultural land into residential land continues to be effective in the production of housing but creates inequity when farmers receive very small compensation for the price. Residential land is sold on the market. The market change from agricultural land to non-agricultural land remains inadequate, mainly due to the legitimate rights of people who have lost their agricultural land, bridge of law, complaints of so many people from everywhere to the central. Therefore, the government should have solutions to reduce inequalities in land compensation for farmers, increase transparency and publicity in the planning and implementation of projects.

Secondly, the weak infrastructure of the real estate market information system, especially the underdeveloped transport system, reduces the attractiveness and scale of the real estate market in Vietnam. The development of real estate projects is still concentrated in urban areas, the development of real estate in remote areas, where infrastructure weaknesses are very limited, scale and real estate investment opportunities are not really expanded to all regions of different regions across the country. Therefore, the government should create policies that reduce inequalities among market participants, and unsecured real estate transactions should be removed from the market. Although the mechanisms and policies for investment activities in general have been unified in the Law on Investment, however, real estate market participants have not actually operated under the same mechanism. (Between organizations and individuals on the mechanism of land allocation, land lease as well as appraisal and issuance of investment certificates, real estate business registration ...).

Third, the development of the real estate market in Vietnam is sometimes spontaneous, lacking in strategy and specific plans. Over time the real estate market, development does not ensure balance; Investors focused only on housing projects and new urban projects to sell to high-income people. Meanwhile, housing projects for sale or rent for rent paid to low-income people have not been paid enough attention. The government needs to change its mechanism and policy to allow more private housing projects to be implemented. Need to eliminate the mechanism that allows state-owned enterprises to develop social housing. The fact that the real estate market in Poland shows that only private firms are effective in producing good and quality homes. The issuance of many policies to encourage private real estate businesses to build social housing is a reasonable solution and should continue to strengthen in the coming time.

Fourth, the undeveloped housing market is commensurate with the needs of society, requiring interventions to promote the development of the real estate market at the request of society. The government should issue policies that encourage private businesses to build houses and rent. The development of the rental housing market will contribute to improving the accessibility of affordable housing. In fact, there is a number of real estate development projects sparse, spontaneous, lacks of orientation to the "freezing" of the real estate market in some localities. 
Fifth, some localities have shown that many real estate projects have been stagnant or delayed compared with the schedule. This situation occurs for a number of reasons, including some of the main reasons that investment projects do not properly assess market demand, so investors lack the capacity, experience and ability difficult financial compensation or compensation, ground clearance is not satisfactory, so prolonged complaints ... The inspection, control and handling of violations of the operation of the real estate market, especially Trading activities are also loosened. Many policies have been effective, but the direction and implementation are slow. Organization of management of the real estate market operating system from the Central is incomplete. The decentralization of management and approval of detailed construction planning at district level is justified; however, due to the fact that the qualifications and professional capacity of the cadres and civil servants in charge of the assigned tasks are insufficient, it requires the government to take measures to improve cadastral officials' Department. In addition, there should be severe punishment, even prosecution of cadastral staff harassment and corruption. The activities of the Anti-Corruption Committee should focus on those working in the real estate sector. In addition, it is necessary to ensure the harmony of the interests of the State, people with real estate and home needs. private Reduce the huge disparity in accommodation between classes in society. Promote the role of the State in orienting, regulating and controlling the operation of the real estate market.

Finally, Vietnam needs to move towards a perfect real estate market, both in terms of organization, structure and organization, to promote the important role of the real estate market for the development of the economy, improving the lives of people in the process of industrialization and modernization of the country. The Government should concentrate on completing, amending and supplementing legal documents to promote the development of the real estate market in line with the law of supply and demand at the same time, ensure social justice with a socialist orientation.

\section{ACKNOWLEDGEMENT}

Thanks the board of director from National Economics University, Department of Finance and Department of Scientific Management to support me in the research. This paper is sponsored by National Economics University, Vietnam.

\section{REFERENCES}

1. Bradsher, Keith (2012-06-10). "Selling Abroad, Chinaeases Slump at Home. "NewYorkTimes.Retrieved 11 June 2012. "The popping of China's real estate bubble over the past year depressed demand for steel, cement and other materials,"

2. Cohen, Roger (2010-01-25). "Burns A Woman." The New York Times, Retrieved 2010-01-25.

3. Chovanec, Patrick (2009-06-08). "China's Real Estate Riddle". Far East Economic Review. Retrieved March 13, 2010.

4. Global property guide (2017), data report 2017

5. Roberts, Dexter (2010-01-05). "China'spropertybubbleunfortunatelyleadtoUS-stylereal-estateslump. "Retrieved 201001-07. "How did this bubble get going? Low interest rates, official Encouragement of Bank Lending, and then Beijing's half-trillion-dollar stimulus plan all made Funds readily available."

6. Nguyen Ba An (2011), "Risk breaking bubble real estate is real", Vietnam Economic Times,

7. Jose Luis Suarez (2009), “European real estate markets”, Palgrave Macmillan Publications.

8. Pham Chi Dung (2017), Real estate bubble has not burst, Vietnam Economic Forum

9. Vu Dinh Son (2017), Real Estate continues to deflate, UK, Thanh Nien newspaper

10. Vu Ngoc Xuan (2014), The Decline in Vietnam Real Estate Market-Lessons from The United States of America and China, Asian Journal of Business and Management, Vol 2, No 1 (2014): February 2014

11. ZhaMinjie (2009-12-09). "Pitching at attended message". Shanghai Daily, Retrieved 2010-01-13.

12. "Why Shanghai Real Estate Is The Most Obvious Bubble Ever". The Business Insider. 2010-01-13. Retrieved 2010-0125. 